\title{
PENGARUH PENGGUNAAN MEDIA PUZZLE GAMBAR BERWARNA DALAM PEMBELAJARAN KOOPERATIF TIPE NHT TERHADAP HASIL BELAJAR BIOLOGI SISWA KELAS XI SMAN 1 KOTO XI TARUSAN
}

\author{
Ristiono, Ernie Novriyanti, Lamia Trisni Yuda \\ Jurusan Biologi FMIPA Universitas Negeri Padang \\ Korespondensi: Jln. Prof. Dr. Hamka Air Tawar, Padang, Sumatera Barat
}

\begin{abstract}
Learning achievement on Biology subject of the eleventh grade students of SMAN I Koto XI Tarusan was still low due to teachers' dominance in learning process, and students' lack of interest toward instructional media used by their teachers. The use colorful puzzled picture for instructional media was expected to be able to stimulate learning activity and arouse students' motivation and, in turns, improve students' learning achievement. This research was therefore aimed at figuring out the effect of using colorful puzzle for instructional media in cooperative learning, especially Number Head Together type, upon Learning achievement on Biology subject of the eleventh grade students of SMAN I Koto XI Tarusan in the academic year of 2010/2011 academic year. This research employed quasi experimental with Static Group Comparison which compares the use colorful puzzled pictures for instructional media and colorful pictures only. The population was all eleventh grade students of SMAN I Koto XI Tarusan in the academic year of 2010/2011 academic year. Sampling technique was purposive where XI IPA5 and XI IPA 6 were chosen. Data from final test was in the form of objective test consisting 40 items were analyzed to test the hypothesis using t-test where if $t_{\text {calculated }}>t_{\text {table, }}$, then the hypothesis was accepted.
\end{abstract}

Kata kunci: puzzle, gambar berwarna, NHT, hasil belajar, biologi

\section{PENDAHULUAN}

$O$ trategi yang digunakan guru akan berpengaruh terhadap respon siswa dalam pembelajaran. Jika guru berhasil menciptakan suasana yang membuat siswa termotivasi aktif dalam belajar, maka akan memungkinkan terjadinya peningkatan hasil belajar siswa. Berdasarkan hasil observasi tim peneliti pada tanggal 18 Februari 2010 di SMAN 1 Koto XI Tarusan, terlihat bahwa proses pembelajaran biologi yang dilakukan guru menggunakan metode ceramah dan guru telah berusaha menciptakan suasana belajar agar siswa lebih aktif dengan menggunakan gambar berwarna dengan bantuan proyektor, namun hasilnya kurang meningkatkan motivasi dan aktivitas siswa secara maksimal. Hal ini disebabkan penggunaan media gambar berwarna yang diberikan guru bersifat satu untuk semua, maksudnya satu gambar yang ditampilkan guru diamati secara bersama-sama oleh siswa, sehingga siswa hanya mendengar, memperhatikan guru menerangkan pelajaran, dan mengerjakan tugas yang diberikan. Proses pembelajaran ini membuat siswa merasa kurang tertarik, kurang termotivasi, dan kurang aktif belajar. Hal tersebut ber- 
dampak terhadap penguasaan konsep pelajaran biologi pada siswa yang rendah, nilai rata-rata ujian mid semester pelajaran biologi siswa kelas XI IPA SMAN I Koto XI Tarusan Semester 1 Tahun Pelajaran 2010/2011 berkisar antara nilai 49,66 sampai 61,59.

Berdasarkan permasalahan di atas, peneliti melakukan upaya mengatasi masalah tersebut dengan melakukan penelitian menggunakan media puzzle gambar berwarna dalam pembelajaran NHT. Proses pembelajaran kooperatif tipe NHT terbagi atas 4 tahap, yaitu tahap penomoran, mengajukan pertanyaan, berpikir bersama, dan menjawab. Pada tahap penomoran, guru membagi siswa menjadi beberapa kelompok dan setiap anggota kelompok diberi nomor. Pada tahap mengajukan pertanyaan, guru mengajukan pertanyaan yang berhubungan dengan materi yang akan dibahas. Pada tahap berpikir bersama, siswa setiap kelompok menyatukan pendapatnya tentang pertanyaan yang diajukan guru. Pada tahap menjawab, guru memanggil salah satu nomor, dan nomor yang terpanggil diminta menjawab pertanyaan untuk seluruh kelas.

Penelitian ini bertujuan untuk mengetahui pengaruh penggunaan media puzzle gambar berwarna dalam pembelajaran kooperatif tipe NHT terhadap hasil belajar biologi Siswa Kelas XI SMAN 1 Koto XI Tarusan Tahun Pelajaran 2010/2011.

Peneliti mengajukan hipotesis berupa penggunaan media puzzle gambar berwarna dalam pembelajaran kooperatif tipe NHT berpengaruh positif terhadap hasil belajar biologi Siswa Kelas XI SMAN 1 Koto XI Tarusan Tahun Pelajaran 2010/2011.

Diharapkan penelitian ini bermanfaat bagi guru biologi dalam memilih dan menggunakan media serta model pembelajaran untuk meningkatkan hasil belajar siswa.

\section{METODE PENELITIAN}

Jenis penelitian yang dilakukan adalah penelitian eksperimen semu. Rancangan yang digunakan adalah The Static Group Comparation, membandingkan penggunaan media puzzle gambar berwarna dengan gambar berwarna tanpa dijadikan puzzle dalam pembelajaran kooperatif tipe NHT. Pada penelitian ini diperoleh sampel sebanyak 65 siswa, yaitu 35 siswa kelas XI IPA-5 dan 30 siswa kelas XI IPA-6, yang telah dipilih dengan teknik purposive sampling dari 206 siswa dalam 6 kelas.

Perlakuan yang diberikan pada kedua kelas sampel dijabarkan berikut ini.

\section{Pendahuluan (10 menit)}

a. Berdoa dan dilanjutkan dengan absensi siswa.

b. Apersepsi

c. Menyampaikan judul dan tujuan pembelajaran

\section{Kegiatan inti (70 menit)}

Fase 1: Guru memberikan materi serta memberikan penekanan pada materi yang akan dijabarkan sesuai dengan standar kompetensi, kompetensi dasar, indikator, materi pokok pada materi yang ingin dicapai.

Fase 2: Penomoran

Guru membagi siswa pada kelompok yang heterogen 3-5 orang. Kemudian menyuruh duduk pada kelompok yang telah ditentukan. Masing-masing anggota kelompok memiliki nomor. Tahapan ini hanya dilaksanakan pada pertemuan pertama, sedangkan pada pertemuan berikutnya, siswa tetap dalam kelompok yang telah ditetapkan pada pertemuan pertama.

Fase 3: Guru menjelaskan kepada siswa tentang cara dan peratur- 
an pelaksanaan kegiatan pembelajaran, dimana setiap kelompok diharuskan menyusun puzle gambar berwarna.

Fase 4: Guru membagikan lembaran diskusi siswa kepada setiap kelompok. Selanjutnya guru membagikan gambar-gambar dalam bentuk puzzle berwarna kepada setiap kelompok.

Fase 5: Mengajukan Pertanyaan

Guru mengajukan pertanyaan yang berhubungan dengan materi yang dibahas. Misal: "Bagaimanakah bentukan struktur jantung pada mammalia?"

Fase 6: Berpikir Bersama

Guru menugaskan setiap kelompok untuk berpikir bersama, guru menugaskan setiap kelompok untuk saling bekerja sama dalam mengamati gambar. Setelah pengamatan selesai maka setiap kelompok menyatukan pendapatnya tentang pertanyaan yang diajukan guru.

\section{Fase 7: Menjawab Pertanyaan}

Guru meminta siswa menjawab pertanyaan. Guru memanggil satu nomor tertentu, kemudian siswa yang bernomor sama mengacungkan tangan dan kemudian siswa yang bernomor sama mengacungkan tangan dan mengemukakan pendapatnya.

\section{Penutup (10 menit)}

a. Siswa bersama guru menyimpulkan materi pelajaran.

b. Guru memberikan informasi dan menyuruh siswa mempelajari materi pelajaran minggu berikutnya.

Instrumen atau alat pengumpul data berupa soal tes tertulis berbentuk objektif tes sebanyak 40 item tes, yang telah memenuhi kriteria validitas berupa indeks kesukaran soal dan daya pembeda soal, dan reliabilitas tes yang dikemukakan oleh Arikunto (2008).
Untuk uji hipotesis, terlebih dahulu dilakukan uji normalitas dan homogenitas. Berdasarkan hasil uji normalitas dan homogenitas data sampel, ternyata data sampel normal dan bervarinsi homogen, sehingga statistik untuk uji hipotesis digunakan uji persamaan dua rata-rata data sampel berupa uji t.

\section{HASIL DAN PEMBAHASAN}

Data penelitian berupa rata-rata nilai hasil belajar siswa dari kedua kelas adalah 74 untuk kelas eksperimen dan 69,6 untuk kelas kontrol. Berdasarkan uji t, ternyata didapatkan bahwa $t_{\text {hitung }}>$ $t_{\text {tabel}}$. Dari hasil perhitungan diperoleh $t_{\text {hitung }}$ sebesar 2,23 dan pada taraf nyata 0,05 didapat harga $t_{\text {tabel }}$ sebesar 1,98 pada derajat kebebasan 63. Dengan demikian $t_{\text {hitung }}>t_{\text {tabel, }}$ dan dapat ditegaskan bahwa hipotesis kerja diterima. Perbandingan hasil uji hipotesis dengan tabel $\mathrm{t}$ dikemukakan dalam tabel di bawah ini.

Tabel Hasil Uji Persamaan Dua RataRata Data Sampel

\begin{tabular}{cccc}
\hline Kelas & $t_{\text {hitung }}$ & $t_{\text {tabel }}$ & Kesimpulan \\
\cline { 1 - 1 } Eksp & 2,23 & 1,98 & $\begin{array}{c}\text { Hipotesis } \\
\text { diterima }\end{array}$ \\
\cline { 1 - 3 } Ktrol & 2,23 &
\end{tabular}

Berdasarkan analisis data terlihat bahwa ada perbandingan hasil belajar dari kedua kelas eksperimen, yaitu nilai rata-rata kelas eksperimen adalah 74 dan kelas kontrol adalah 69,6. Dari nilai rata-rata tersebut terlihat bahwa nilai eksperimen lebih tinggi dibandingkan kelas kontrol.

Pada prinsipnya pemberian kedua bentuk media pembelajaran ini samasama dapat meningkatkan hasil belajar karena dengan menggunakan media pembelajaran dapat merangsang aktivitas dan memacu motivasi belajar siswa sehingga akan diperoleh hasil belajar yang lebih baik. Sebagaimana yang dinyatakan Wena (2010: 15) "keter- 
sediaan media pembelajaran sangat mempengaruhi hasil belajar siswa".

Pada kenyataannya, siswa yang proses pembelajarannya menggunakan media puzzle gambar berwarna memperoleh rata-rata hasil belajar lebih tinggi daripada siswa yang proses pembelajarannya menggunakan media gambar berwarna. Kenyataan ini karenapenggunaan puzzle gambar berwarna mengharuskan siswa untuk menyusun sendiri potongan-potongan gambar menjadi gambar yang utuh, sehingga dapat memahami maksud dari gambar tersebut. Pembelajaran kooperatif tipe NHT yang perlakuannya menggunakan media puzzle gambar berwarna meningkatkan interaksi sesama anggota kelompok. Seperti yang diungkapkan oleh Mia (2010), bahwa merakit puzzle yang dilakukan oleh siswa secara kelompok akan meningkatkan interaksi sosial siswa. Siswa di dalam kelompok akan saling menghargai, saling membantu, dan berdiskusi antara satu dengan lainnya.

Kelas kontrol yang pembelajaran NHT menggunakan media gambar ber-

\section{DAFTAR RUJUKAN}

Ahsanudin, Mohammad. 2006. http:// researchengines.com/0106moh.ht ml. Diakses 23 Maret 2010

Anonimous.2006.http://www.ibudanana k.com/index.php?option $=$ com_new $s \&$ task $=$ view $\&$ id $=169 \&$ ite mid=19. Diakses 23 Maret 2010.

Arikunto, Suharsimi. 2008. Dasar-dasar Evaluasi Pendidikan. Jakarta: Bumi Aksara.

Arsyad, Azhar.2002. Media Pembelajaran. Jakarta: PT.Raja Grafindo Utama

Djamarah, Syaiful Bahri dan Aswan Zain. 2006. Strategi Belajar Mengajar. Jakarta: PT Rineka Cipta. warna memperoleh rata-rata hasil belajar yang lebih rendah daripada kelas eksperimen yang menggunakan media puzzle gambar berwarna Hal ini karena media gambar berwarna tanpa diperlakukan tidak membuat siswa berpikir lebih lanjut. Siswa lebih cenderung mengamati saja tanpa berbuat, sehingga kurang memahami makna dari gambar tersebut. Akibatnya, pesan yang disampaikan gambar berwarna tersebut kurang dipahami secara utuh oleh siswa.

\section{PENUTUP}

Berdasarkan hasil penelitian yang telah dilakukan, maka dapat disimpulkan bahwa penggunaan media puzzle gambar berwarna berpengaruh positif terhadap hasil belajar biologi siswa kelas XI SMAN 1 Koto XI Tarusan tahun pelajaran 2010/2011. Hasil belajar siswa yang menggunakan media puzzle gambar berwarna lebih baik daripada yang menggunakan media gambar berwarna.

Deli, Sikhtin Mutia. 2010. Studi Perbandingan Hasil Belajar Siswa antara penggunaan media gambar bernomor dan media gambar dengan keterangan dalam model pembelajaran kooperatif tipe Numbered Head Together pada siswa kelas XI A semester II Solok selatan tahun pelajaran 2009/2010. Skripsi. Padang: UNP.

Effendi, Shintya. 2009. Pengaruh Penggunaan Media Permainan Puzzle Berbasis Gambar dan Peta Konsep dalam Pembelajaran Kooperatif Tipe Student Teams Achievement Division (STAD) terhadap Hasil Belajar Biologi Kelas XI Siswa SMAN 3 Kota 
Solok Tahun Pelajaran 2008/2009. Skripsi: UNP.

Hamalik, Oemar. 2002. Perencanaan Pengajaran Berdasarkan Pendekatan Sistem. Jakarta: PT Bumi Aksara.

Harianti, Deasy. 2008. Metode Jitu Meningkatkan Daya Ingat. Jakarta: Tangga Pustaka

Harjanto. 2005. Perencaan Pengajaran. Jakarta: Rineka Cipta.

Lungdren. 1994. http://www.ditnagadikti.org/ditnaga/files/PIP/koopera tif.pdf. Diakses 23 Maret 2010.

Lufri. 2007. Strategi Pembelajaran Biologi. Padang: UNP Press.

Mia, miashop. 2010. file:///G:/media2. html. Diakses 12 Januari 2011.

Rohani, Ahmad dan Abu Ahmadi. 1991. Pengelolaan Pengajaran. Jakarta: PT Rinake Cipta.

Rahayu, Sri. 2009. http://pelawiselatan. blogspot.com/2009/03/numberhead-together-html. Diakses 23 Maret 2010.

\section{Indeks}

belajar. $1,106,107,108$

gambar 1, 106, 107, 108, 109

guru $1,106,107$
Sadiman, Arief S. 2006. Media Pendidikan. Jakarta: PT Raja Grafindo Persada.

Slameto, 2003. Belajar dan Faktor yang Mempengaruhi. Jakarta: PT. Rineka Cipta.

Sudjana. 2005. Metode Statistika. Bandung: PT. Tarsito.

Sudjana, Nana. 2003. Teknologi Pengajaran. Bandung: Sinar Baru.

Suryabrata, Sumadi. 2010. Metodologi Penelitian. Jakarta: Raja Grafindo Persada.

Tryana, Antin. 2008. Penerapan Model Pembelajaran Kooperatif Numbered Heads Together (NHT) http://iqbalali.com/2010/01/03/nht -numbered-head-together. Diakses 23 Maret 2010.

Usman, M. Uzer. 2010. Menjadi Guru Profesional. Bandung: PT. Remaja Roesdakarya offset.

Wena, Made. 2010. Strategi Pembelajaran Inovatif Kontemporer. Jakarta: PT. Bumi Aksara.

media $1,106,108,109$

puzzle $1,106,107,108$ siswa 1, 106, 107, 108, 109 